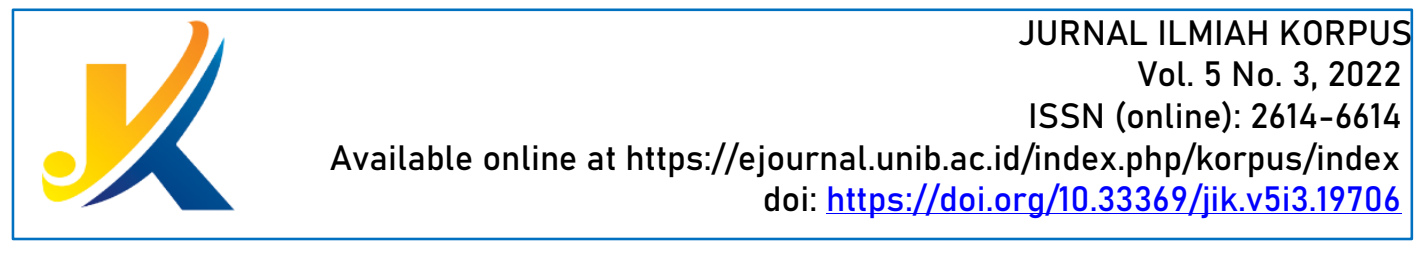

KEKERASAN DALAM ROMAN ANGKATAN 20-an

\author{
${ }^{1}$ Ade Oktasari; ${ }^{2}$ Sarwit Sarwono; ${ }^{3}$ Fina Hiasa \\ 1,2,3 Program Studi Pendidikan Bahasa Indonesia FKIP Universitas Bengkulu
}

Abstrak

\title{
Korespondensi: aaaoktas@gmail.com
}

Penelitian ini membahas tentang Kekerasan Dalam Roman Angkatan 20-an. Metode yang digunakan dalam penelitian ini adalah metode desktiptif kualitatif dengan analisis teks. Penelitian ini bertujuan untuk mengkaji roman angkatan 20an menggunakan pendekatan sosiologi sastra dari sisi isi karya sastra. Data dalam penelitian ini berupa kutipan-kutipan kalimat ataupun paragraf yang mencerminkan tindak kekerasan dalam roman angkatan 20-an. Teknik yang digunakan dalam pengumpulan data adalah teknik baca dan tulis. Teknik analisis data yang digunakan dalam penelitian ini yaitu membaca roman angkatan 20-an, menandai dan mencatat, mengidentifikasi, menggolongkan, menganalisis, mendeskripsikan dan membuat kesimpulan. Hasil penelitian ini menunjukakan bahwa: terdapat dua bentuk tindakan kekerasan dalam roman-roman angkatan 20an, yaitu kekerasan verbal dan kekerasan fisik. Bentuk kekerasan verbal dalam roman angkatan 20-an ini berupa pengancaman, membentak, umpatan, berteriak keras, memanipulasi, memfitnah, pembatasan, memprovokasi, menuduh, pemaksaan, dan mencemooh. Sementara untuk bentuk kekerasan fisik dalam roman angkatan 20-an ini berupa pemukulan, penelantaran anak, eksploitasi anak, pembunuhan, pengabaian, penghilangan harta benda, pemukulan, perkelahian, dan penganiayaan. Terdapat latar sosial budaya dalam roman angkatan 20-an meliputi: (1) kebudayaan, (2) ekonomi, dan (3) kekuasaan.

Kata Kunci: Kekerasan, roman angkatan 20-an, dan latar sosial budaya.

\begin{abstract}
This study discusses violence in the Romans of the 20s. The method used in this study is a qualitative descriptive method with text analysis. This study aims to examine the novels of the 20 s generation using the sociology of literature approach in terms of the content of literary works. The data in this study are in the form of excerpts from sentences or paragraphs that reflect acts of violence in the novels of the 20 s generation. The technique used in data collection is the reading and writing technique. The data analysis techniques used in this study were reading novels from the 20s, making a synopsis, marking and recording, classifying, analyzing, and drawing conclusions. The results of this study indicate that: there are two forms of acts of violence in the romances of the 20s generation, namely verbal violence, and physical violence. The forms of verbal violence in this novel of the $20 \mathrm{~s}$ are threatening, yelling, swearing, shouting, manipulating, slandering, restricting,
\end{abstract}


provoking, accusing, coercing, and ridiculing. Meanwhile, the forms of physical violence in this 20s generation novel are beatings, child neglect, child exploitation, murder, neglect, loss of property, beatings, fights, and abuse. There are sociocultural backgrounds in the novels of the 20s, including: (1) culture, (2) economy, and (3) power.

Keywords: Violence, 20's generation romance, and socio-cultural background.

\section{PENDAHULUAN}

Karya sastra seringkali dijadikan sebagai wadah oleh para pengarang untuk mengekspresikan kehidupan sosial dalam masyarakat baik itu perilaku seorang individu ataupun berkelompok ke dalam sebuah tulisan yang indah. Karya sastra juga mengungkapkan fenomena sosial perihal permasalahan manusia dan kemanusiaan, serta menggambarkan tentang penderitaan yang dialami oleh manusia, berbagi rasa cinta kasih, dan segala hal yang dilakukan untuk memenuhi nafsu pribadi. Fenomena sosial tersebut sangat memungkinkan munculnya konflik-konflik yang disebabkan oleh adanya pertentangan yang terjadi yang seringkali menjadi pemicu utama terjadinya sebuah tindakan kekerasan, baik berupa kekerasan fisik, ataupun kekerasan verbal. Kekerasan sendiri dapat terbagi menjadi beberapa macam. Kekerasan terbagi berdasarkan tempat kejadiannya dan bagaimana suatu kekerasan itu berlangsung. Salah satu penggolongan kekerasan yaitu kekerasan di dalam keluarga yang berupa berupa kekerasan fisik, kekerasan seksual, dan anak anak yang menyaksikan berbagai bentuk kekerasan (Prawestiningtyas, 2017:113).

Karya sastra tidak hanya membahas perihal keromantisan namun juga membahas mengenai konflik-konflik dalam masyarakat yang diciptakan oleh seorang pengarang serta dianggap sebagai sebuah cerminan kehidupan bermasyarakat. Salah satu fenomena kekerasan yang saat ini marak terjadi dalam kehidupan masyarakat saat ini yaitu kasus bullying. Bullying yang dalam bahasa Indonesia berarti penindasan atau risak merupakan bentuk kekerasan yang dilakukan secara sengaja oleh seseorang atau sekelompok orang yang berkuasa atau yang lebih kuat terhadap orang lain yang bertujuan untuk menyakiti serta dilakukan secara terus menerus (www.kemenpppa.go.id). Tindakan kekerasan yang dilakukan oleh seseorang atau sekelompok orang yang memiliki kekuasaan atau yang berkuasa pada dasarnya sudah sering terjadi bahkan dari sejak zaman dulu. Tindak kekerasan yang terjadi dalam masyarakat tersebut, tercermin dalam sebuah karya sastra khususnya dalam prosa.

Pada penelitian ini, penulis membahas tentang kekerasan yang terjadi dalam roman terbitan Balai Pustaka angkatan 20-an. Roman adalah salah satu jenis prosa yang usianya lebih tua dari novel serta terkenal di era tahun 1920-an. Roman terbitan Balai Pustaka khususnya angkatan 20-an memiliki karakteristik yaitu sebagian besar roman pada masa itu mengisahkan romansa tentang pertentangan paham antara kaum muda dan kaum tua, permasalahan adat istiadat serta perihal kawin paksa yang termasuk ke dalamnya adalah permaduan (Pradopo, 1995:14). Karakteristik roman yang cenderung menimbulkan konflik tersebut menghasilkan tindakan-tindakan kekerasan yang terjadi antara tokoh satu dengan tokoh yang lainnya.

Tindakan-tindakan kekerasan yang muncul dalam roman angkatan 20-an tersebut, terjadi sebab latar sosial budaya yang terdapat dari masing-masing roman. Latar sosial 
budaya yang terdapat dalam roman angkatan 20-an salah satunya ialah kekuasaan. Menurut Max Weber (dalam Santoso, 2001:59) mendefinisikan kekuasaan sebagai sebuah kesempatan yang dimiliki oleh seseorang atau sejumlah orang untuk melaksanakan keinginannya sendiri dalam suatu tindakan sosial, meskipun mendapat tantangan dari orang lain yang terlibat dalam tindakan itu.

Oleh karena itu, pada penelitian ini penulis berusaha untuk mengungkapkan latar sosial budaya yang terdapat dalam roman angkatan 20 -an yang menyebabkan timbulnya tindak kekerasan dan menghasilkan bentuk-bentuk kekerasan dalam roman angkatan 20an dengan menggunakan pisau bedah sosiologi sastra. Sosiologi dan sastra merupakan ilmu yang memiliki objek kajian yang sama tentang kehidupan manusia dalam masyarakat guna memahami hubungan-hubungan yang terjalin antar manusia yang timbul akibat dari proses hubungan-hubungan tersebut dalam masyarakat. Fakta-fakta di dalam sosiologi dengan sendirinya dipersiapkan dan dikondisikan oleh masyarakat, keberadaannya selalu dipertimbangkan dalam hubungannya dengan fakta sosial yang lain, yang juga telah dikondisikan secara sosial (Ratna, 2013:36).

Melalui teori sosiologi sastra, maka penulis berusaha untuk melihat hubunganhubungan yang terjalin antar tokoh-tokoh yang ada dalam roman-roman tersebut sehingga ditemukanlah bentuk-bentuk kekerasan dalam roman angkatan 20-an. Berdasarkan pendahuluan yang diuraikan di atas, maka penulis mengambil judul penelitian yaitu "Kekerasan Dalam Roman Angkatan 20-an".

\section{METODE}

Metode yang digunkan dalam penelitian ini adalah metode deskriptif kualitatif dengan metode analisis teks. Penelitian ini menggunakan pendekatan sosiologi sastra. Sumber data pada penelitian ini yaitu roman si Jamin dan si Johan karya Merari Siregar, roman Siti Nurbaya karya Marah Rusli, roman Azab dan Sengsara karya Merari Siregar, roman Sengsara Membawa Nikmat karya Tulis Sutan Sati dan roman Salah Asuban karya Abdoel Moeis. Data dalam penelitian ini berupa kutipan-kutipan kalimat ataupun paragraf yang mencerminkan tindak kekerasan dalam roman angkatan 20-an. Teknik yang digunakan dalam penelitian ini adalah teknik baca dan tulis. Teknik analisis data yang digunakan dalam penelitian ini ialah teknik deskriptif kualitatif berupa membaca roman angkatan 20-an, menandai dan mencatat, mengidentifikasi, menggolongkan, menganalisis, mendeskripsikan dan membuat kesimpulan.

\section{HASIL DAN PEMBAHASAN}

Berdasarkan penelitian yang telah penulis lakukan, penulis menemukan bahwa terdapat bentuk-bentuk tindak kekerasan dalam roman angkatan 20-an antara lain berupa kekerasan verbal dan kekerasan fisik. Bentuk kekerasan dalam roman tersebut muncul sebagai sebuah cerminan dari fenomena sosial yang terjadi di dalam masyarakat pada masa itu. Bentuk-bentuk kekerasan tersebut muncul berdasarkan dengan permasalahan yang terjadi di dalam roman. Berikut ini adalah pemaparan dari bentuk kekerasan dalam roman angkatan 20-an:

\section{Bentuk kekerasan verbal}

a. Kekerasan Verbal dalam Roman si Jamin dan si Johan Karya Merari Siregar 
Roman si Jamin dan si Johan ini mengisahkan tentang kehidupan dua bersaudara yang masih kecil yaitu Jamin dan Johan dalam menjalani kehidupan mereka yang penuh dengan perjuangan serta cara mereka untuk tetap bertahan dalam menghadapi perlakuan kasar dari ibu tiri mereka.

Dalam roman ini, kekerasan kerap diterima oleh Jamin yang dilakukan oleh ibu tiri mereka yaiu Inem. Jamin kerap kali di ancam oleh Inem apabila Jamin tidak bisa memenuhi keinginan dan kemauan Inem. Kekerasan verbal dalam roman si Jamin dan si Johan ini dapat dilihat berdasarkan kutipan berikut.

"kalau engkau tidak mau, kucekik lehermu, dan adikmu ku buang ke kali". Hal-33

Dari kutipan tersebut tampak bahwa kekerasan verbal berupa ancaman yang diberikan oleh Inem membuat Jamin menjadi ketakutan dan khawatir. Jamin yang masih kecil harus menerima ancaman-ancaman yang sangat kasar seperti itu dari mulut orang dewasa. Hal ini tentu saja membuat Jamin menjadi sangat khawatir terhadap adiknya Johan. Ia takut kalau saja Inem benar-benar akan membuang Johan ke kali atau sungai bila ia tidak membawa uang dengan jumlah yang diharapkan oleh Inem.

\section{b. Kekerasan Verbal dalam Roman Sitti Nurbaya Karya Marah Rusli}

Roman Siti Nurbaya ini menceritakan tentang perkawinan paksa yang dilakukan oleh Datuk Meringgih terhadap Nurbaya. Nurbaya yang tidak berdaya menentang kekuasaan yang dimiliki Datuk Meringgih harus merelakan kehidupan masa mudanya untuk melindungi orang yang ia sayangi.

Kekerasan verbal dalam roman Siti Nurbaya ini bermula saat Datuk Meringgih mengancam Baginda Sulaiman untuk memenjarakannya jika hutang yang ia miliki tidak dapat ia bayar. Hal ini dapat dibuktikan pada kutipan berikut ini.

"tatkala mendengar perkataan ayahku ini, merentaklah ia dengan marahnya, lalu berkata, 'jika demikian, tanggunglah oleh mu!' lalu diserahkannya perkara itu kepada pegawai Belanda yang datang bersama-sama dengan dia. Seorang daripada tuan ini berkata, sambil mendekati ayahku, 'walaupun dengan sedih hati, tetapi terpaksa hamba akan membawa tuan ke dalam penjara atas kemauan Datuk Meringgih.” Hal-150.

Berdasarkan kutipan di atas tampak bahwa Datuk Meringgih menjadi marah setelah tau bahwa niatnya untuk menikahi Nurbaya ditolak oleh Baginda Sulaiman. Selain itu, Baginda Sulaiman juga tidak dapat membayar hutangnya kepada Datuk Meringgih lantaran ia sudah tidak lagi memiliki uang karena semua harta bendanya sudah habis dimusnahkan oleh Datuk Meringgih sendiri. Berdasarkan kutipan tersebut tampak bahwa Baginda Sulaiman akan dibawa ke penjara jika ia tidak dapat melunasi hutangnya tersebut. Oleh karena itu, Nurbaya akhirnya menyerahkan dirinya kepada Datuk Meringgih untuk diperistri. Nurbaya harus merelakan dirinya untuk melindungi ayahnya dari jeratan penjara yang akan dilakukan oleh Datuk Meringgih.

Berdasarkan hal di atas maka tampak bahwa kekerasan verbal yang berujung pada pengendalian ini dilakukan oleh Datuk Meringgih terhadap Baginda Sulaiman. Secara tidak langsung, Datuk Meringgih berhasil mengontrol Baginda Sulaiaman untuk memberikan apa yang ia inginkan dengan alibi hutang piutangnya. 
Pengendalian ini terlihat saat Datuk Meringgih sengaja meminjamkan uangnya kepada Baginda Sulaiman dengan maksud lain. Ia meminjamkan uang tersebut bukan untuk berniat baik membantu Baginda Sulaiman, namun ia mengharapkan sebuah imbalan yang lebih dari Baginda Sulaiman yaitu mendapatkan Nurbaya.

\section{c. Kekerasan Verbal dalam Roman Azab dan Sengsara Karya Merari Siregar}

Roman Azab dan Sengsara ini merupakan roman yang dipenuhi dengan kisah cinta romantis antara Aminudin dan Mariamin yang tidak mungkin bersatu karena terhalang status dan hierarki pada zaman itu. Perekonomian dijadikan sebagai sebuah tolak ukur pantas atau tidaknya seseorang untuk mendapatkan hal yang sudah sekian lama ia cita-citakan dan ia perjuangkan

Dalam roman Azab dan Sengsara ini, kekerasan verbal banyak dilakukan oleh Sutan Baringin kepada istrinya yaitu Nuria. Sutan Baringin kerap kali membentak Nuria dan cenderung mendiskriminasi peran perempuan sebagai seorang istri. Hal ini dapat dibuktikan dalam kutipan berikut ini.

"Akan tetapi apakah kesudahannya? Sekalian ikhtiar istrinya itu sia-sia. Suaminya tinggal menegangkan urat lehernya. Pengajaran setan manusia yang berlidah petah itu, sudah masuk benar ke hatinya, dan matanyapun sudah tak melihat lagi, bagaimana kesudahannya perbuatannya itu di belakang hari. Akan mengerasi dan memaksa suaminya itu ia tak berani. Perempuan yang berhati lemah lembut itu karena amatlah hormatnya kepada suaminya itu. Memberi ingat suamipun tiada berani lagi ia, sejak Sutan Baringin membentak ia dengan perkataan, "Diam kau; perempuan tiada takut mencampuri urusan laki-laki, dapur sajalah bagianmu!” Hal-23.

Berdasarkan kutipan di atas tampak bahwa Sutan Baringin tidak memberikan kesempatan kepada istrinya yaitu Nuriah untuk menyampaikan nasihat ataupun pendapatnya kepada Sutan Baringin sendiri. Berdasarkan kutipan di atas tampak bahwa Sutan Baringin melakukan kekerasan kepada Nuria berupa kekerasan verbal dengan bahasa isyarat. Sutan Baringin yang menegangkan urat lehernya menandakan bahwa ia sedang dalam keadaan yang marah dan kemudian membentak Nuria yang ingin menasihati suaminya sendiri. Rasa hormat Nuriah kepada suaminya menyebabkan ia diperlakukan semena-mena oleh Sutan Baringin. Sifat Sutan Baringin yang keras kepala dan tidak mau mengalah itu menyebabkan semua usaha istrinya untuk memperingatkannya ataupun menasihatinya sia-sia saja. Sutan Baringin tidak pernah mau mendengarkan apa yang disampaikan oleh istrinya. Selain itu, dalam kutipan tersebut juga tampak bahwasannya Nuria tidak berdaya untuk melawan Sutan Baringin.

Selain membentak Nuria, dari kutipan di atas juga tampak adanya sebuah diskriminasi yang dilakukan oleh Sutan Baringin kepada Nuria. Diskriminasi ini tampak saat Sutan Baringin menyatakan bahwa seorang perempuan tidak boleh atau tidak pantas untuk ikut campur urusan laki-laki dan hanya boleh mengurus dapur saja. Berdasarkan hal itu, maka tampak bahwa Sutan Baringin sudah membatasi hak Nuriah sebagai istrinya untuk menasihati Sutan Baringin atas kelakuannya demi kebaikan keluarga mereka. Selain membatasi Nuriah untuk menyampaikan pendapatnya, pernyataan yang disampaikan oleh Sutan Baringin tersebut juga cenderung meremehkan peran kaum wanita pada masa itu, yang mana kaum wanita 
hanya diperbolehkan untuk mengurus urusan di dapur saja tanpa boleh tau apa yang sebenarnya terjadi dan tindakan apa yang sebaiknya dilakukan.

\section{d. Kekerasan Verbal dalam Roman Salah Asuhan Karya Abdoel Moeis}

Roman Salah Asuhan ini mengisahkan tentang perjalanan hidup seorang Hanafi ketika mengejar cinta Corrie dan juga penanggungan ibu Hanafi dalam menghadapi sifat Hanafi yang melenceng dari budaya Timur dan bersifat kebarat-baratan. Hanafi selalu saja meremehkan kaumnya sendiri yaitu kaum Pribumi. Hanafi menganggap bahwa dirinya memiliki derajat lebih tinggi dari kaumnya sendiri dan sejajar dengan bangsa Belanda.

Kekerasan verbal dalam roman ini terjadi sebab perbedaan kebudayaan antara budaya timur dan budaya barat yang dianut oleh Hanafi. Hanafi yang merupakan anak pribumi tidak mau mengikuti adat istiadat yang berlaku di kampungnya. Ia bahkan menganggap remeh adat tersebut dan selalu mencemooh bangsanya sendiri. Hal ini dapat dibuktikan pada kutipan di bawah ini.

"Itulah salahnya, Ibu, bangsa kita dari kampung; tidak suka menurutkan putaran zaman. Lebih suka duduk rungkuh dan duduk mengukur saja sepanjang hari. Tidak ubah dengan kerbau bangsa kita, Bu! dan segala sirih menyirih itu... Brrr!"” Hal-25.

Berdasarkan kutipan tersebut, tampak bahwa Hanafi mencemooh bangsanya sendiri dengan mengatakan bahwa bangsanya berasal dari kampung dan tidak bisa mengikuti putaran zaman pada masa itu. Cemoohan atau hinaan lain yang dilontarkan oleh Hanafi ini ia sampaikan kepada ibunya untuk merepresentasikan bangsa pribumi. Hanafi menyamakan bangsa pribumi dengan seekor kerbau. Hal tersebut tentulah sangat menghina dan merendahkan martabat bangsa pribumi.

Selain itu, dalam kutipan tersebut tampak bahwa Hanafi tidak menghargai kebiasaan menyirih yang sudah menjadi kebiasaan yang dilakukan oleh orang tua di kampungnya pada zaman dulu. Hanafi menganggap bahwa kebiasaan yang serupa itu tidak sesuai dengan zaman dimana ia berada. Selanjutnya, dari kutipan tersebut pun tampak bahwa Hanafi merupakan seorang yang angkuh dan enggan mengakui kebiasaan tersebut sebagai adat dirinya sebagai seorang pribumi. Penghinaan ini termasuk pula ke dalam bentuk kekerasan verbal. Selain mencemooh atau menghina adat dan kebiasaan bangsanya, Hanafi bahkan tidak segan-segan untuk menghina agama yang dianut oleh bangsa Melayu. Bahkan hinaan yang sering ia lontarkan ini menyebabkan ia menjadi tidak memiliki teman dan hidup tersisih dari kehidupan adat istiadat di kampungnya.

\section{e. Kekerasan Verbal dalam Roman Sengsara Membawa Nikmat Karya Tulis Sutan Sati}

Roman Sengsara membawa nikmat ini mengisahkan tentang perjuangan hidup seorang laki-laki bernama Midun yang selalu saja dicelakai oleh Kacak yang merupakan bangsawan di kampungnya. Kacak rela melakukan semua cara agar Midun bisa menderita dan keluar dari kampung halamannya. Kekuasaan yang dimiliki oleh Kacak menyebabkan dirinya bertingkah semena-mena, bahkan warga kampung pun banyak yang tidak menyukai Kacak. Warga kampung tersebut 
menghormati Kacak lantaran Kacak adalah kemenakan atau keponakkan Tuanku Laras yang merupakan bangsawan terhormat di kampungnya.

Kekerasan verbal dalam roman ini terjadi di antara Kacak dan Midun. Kacak yang sangat iri dan dengki pada Midun selalu saja mencari-cari kesalahan Midun. Kacak pun pernah memfitnah Midun di depan hadapan Tuanku Laras dengan menyatakan bahwa Midun sengaja melukai pak Inuh yang sedang mengamuk di pasar. Pak Inuh adalah salah seorang keluarga dari Tuanku Laras yang sedang mengalami gangguan jiwa. Hal ini dapat dibuktikan pada kutipan berikut ini.

"Sekarang nyata, bahwa Midun musushku. Kata Kacak dalam hatinya, sudah engkau lukai mamakku, engkau bebat. Maksudmu tentu supaya kami jangan marah. Kurang ajar sungguh! Hati-hati engkau, besok dapat bagian daripadaku. Bila Tuanku Laras pulang dari Bukittinggi, kuceritakan hal itu kepadanya. Anak si peladang jahanam, berani melukai family raja di kampung ini!" hal-34.

Berdasarkan kutipan di atas, tampak bahwa Kacak sudah salah menuduh Midun yang tidak-tidak. Kacak bahkan menghina Midun sebagai seorang jahanam. Berdasarkan kutipan tersebut, juga terlihat bahwa Kacak mengadukan perbuatan Midun kepada Tuanlu Laras tanpa mengetahui dan mengakui kebenarannya. Karena hal inilah, akhirnya Midun dipanggil oleh Tuanku Laras ke rumahnya untuk diberikan hukuman atas pengaduan yang disampaikan oleh Kacak. Pengaduan yang disampaikan oleh Kacak kepada Tuanku Laras ini merupakan sebuah kekerasan verbal karena pengaduan yang dibuat oleh Kacak tersebut mengandung unsur memfitnah dan menyebabkan Midun harus dikenai hukuman. Kacak mengatakan bahwa Midun dengan sengaja melukai Pak Inuh, namun pada kenyataannya bahwa Pak Inuhlah yang ingin menikam Midun dan Midun hanya membela dirinya. Tuanku Laras tidak mempercayai Midun dan tetap memberikan hukuman kepadanya.

\section{Bentuk Kekerasan Fisik}

a. Kekerasan Fisik dalam Roman si Jamin dan si Johan Karya Merari Siregar

Roman si Jamin dan si Johan menceritakan tentang kekerasan fisik yang selalu diterima oleh tokoh Jamin berupa perlakuan kasar seperti pemukulan dan pemaksaan serta perampasan hak anak untuk bermain dan mendapatkan kasih sayang dari kedua orang tua mereka. Kekerasan fisik ini tidak hanya ditujukan oleh Jamin dan Johan melainkan juga kepada Mina, yaitu ibu kandung Jamin dan Johan.

Jamin dan Johan hanya bisa berpasrah diri saja saat diperlakukan kasar oleh Inem yang merupakan ibu tiri mereka. Jamin dan Johan tidak berdaya membalas ataupun melawan perbuatan Inem. Mereka tidak memiliki tenaga. Inem bahkan bisa berbuat semaunya saja kepada dua bersaudara ini. Hal ini dapat dibuktikan pada kutipan di bawah ini.

" si Inem berbuat sesuka hatinya kepada kedua anak itu. Pekerjaan yang tiada patut, disuruhnya kerjakan. Jikalau budak-budak itu lambat pula atau lalai sedikit saja, tempeleng dan maki perempuan itu tak hentinya. Kalau ada pekerjaan, anak itu tak dibiarkannya berhenti sebelum pekerjaan itu selesai. Kadang-kadang sampai jauh malam baru anak itu dapat tidur. Pagi-pagi benar si Inem membangunkannya dengan laku kasar dan bengis. Kalau anak itu tak 
lekas berdiri sebab belum puas tidur, perempuan itu menariknya dengan keras dari tempat tidur. Si Jamin hanya menangis saja. Akan melawan ia tak berani. Biasanya dalam keadaan yang begitu si Johan menangis melihat nasib abangnya. Akhirnya kedua anak itu bertangis-tangisan dengan sedihnya." Hal-32.

Berdasarkan kutipan tersebut, membuktikan betapa jahatnya Inem dan betapa berat siksa yang harus dirasakan oleh dua bersaudara ini. Inem tanpa rasa ragu melakukan kekerasan fisik seperti menempeleng anak kecil itu. Inem selalu menyiksa Jamin sehingga menyebabkan fisik mereka menjadi lemah dan tak berdaya. Inem selalu melakukan ekslopitasi anak kepada Jamin. Berdasarkan kutipan tersebut pun tampak bahwa Jamin di paksanya untuk bekerja hingga larut malam dan kembali bangun untuk bekerja pagi-pagi.

Berdasarkan kutipan tersebut, tampak bahwasannya Inem selalu menyuruh Jamin mengerjakan pekerjaan yang seharusnya tidak layak untuk dilakukan oleh anak-anak. Tindakan kasar Inem seperti menarik paksa Jamin dari tempat tidur untuk pergi bekerja tersebut, menggambarkan bahwa keadaan Jamin yang sangat tidak berdaya dalam melawan atau menghentikan tindakan semena-mena yang dilakukan oleh Inem terhadap dirinya. Tidak jarang kedua bersaudara ini harus menahan lapar setiap hari karena uang hasil meminta-minta yang didapatkan Jamin selalu diambil oleh Inem sepenuhnya untuk membeli candu.

\section{b. Kekerasan Fisik dalam Roman Sitti Nurbaya Karya Marah Rusli}

Roman Sitti Nurbaya ini mengisahkan kekuasaan yang dimiliki oleh Datuk Meringgih yang menyebabkan orang-orang yang memiliki urusan dengannya tidak berdaya melawan dan selalu menuruti perintahnya. Pada roman ini, kekerasan fisik bermula saat Datuk Meringgih selalu mencoba untuk memusnahkan semua harta benda milik Baginda Sulaiman, yaitu ayah kandung dari Sitti Nurbaya. Tidak hanya sebatas itu, setelah mendapatkan apa yang diinginkannya, Datuk Meringgih kembali melakukan kekerasan fisik terutama kepada Sitti Nurbaya.

Usaha pembunuhan selalu dilakukan oleh Datuk Meringgih yang ditujukan kepada Nurbaya. Usaha pembunuhan ini terjadi saat Nurbaya sedang bermalam di tempat Alimah, ternyata Datuk Meringgih menyuruh pendekar Lima dan pendekar Empat untuk bekerjasama meracuni Nurbaya. Atas perintah dari Datuk Meringgih ini, akhirnya pendekar Empat menyamar menjadi penjual kue. Kue tersebut sudah diberikan racun oleh pendekar Empat. Ketika malam tiba, Nurbaya dan Alimah sedang mengobrol dan pada saat itulah pendekar Empat mulai menjajah kuenya.

Alimah sempat bingung, karena tidak biasanya tukang kue berjualan hingga malam, namun karena Nurbaya sudah sangat selera akhirnya dipanggil penjual kue itu. Nurbaya membeli lemang yang mana lemang tersebut sudah diberi racun oleh pendekar Empat. Ketika Nurbaya memakan lemang itu, kepalanya langsung pusing dan badannya langsung terasa tidak enak. Hal ini dapat dibuktikan pada kutipan di bawah ini.

"Walaupun Nurbaya telah terlena, masih dipijit juga oleh Alimah kepalanya, sampai beberapa lamanya. Ia takut adiknya itu akan terbangun pula karena kurang enak rasa badannya; apalagi karena Nurbaya rupanya senang kena pijitnya, sebab lekas ia tertidur. 
Ketika ia berdiri hendak pergi tidur pula, diperhatikanlah muka adiknya itu. Sangatlah ia terperanjat melihat Nurbaya, sebagai tiada bernafas lagi, lalu diguncangkannyalah badan Nurbaya supaya bangun. Tapi sesungguhnyalah, perempuan yang malang itu tak ada lagi." Hal-278.

Berdasarkan kutipan tersebut, tampak bahwa rencana Datuk Meringgih ingin membunuh Nurbaya telah berhasil ia lakukan. Datuk Meringgih berhasil membunuh Sitti Nurbaya dengan cara meracuninya. Datuk Meringgih belum merasa puas jika keinginannya yaitu Nurbaya meninggal belum terpenuhi. Kekerasan fisik yang terjadi pada Nurbaya tersebut dengan terang-terangan dilakukan oleh Datuk Meringgih. Ia selalu mencari dan menghalalkan semua cara agar Nurbaya bisa meninggal di tangannya.

\section{c. Kekerasan Fisik dalam Roman Azab dan Sengsara Karya Merari Siregar}

Pada roman Azab dan sengsara ini, terdapat kekerasan fisik yang diterima oleh tokoh Mariamin yang dilakukan oleh tokoh Kasibuan. Kasibuan adalah suami Mariamin. Kekerasan fisik ini terjadi sebab sikap Kasibuan yang keras dan selalu menaruh cemburu kepada Mariamin. Pernikahan Mariamin dan Kasibuan tidak berjalan dengan baik. Pernikahan yang tidak dilandasi oleh rasa cinta itu menyebabkan Mariamin menjadi tersiksa.

Kekerasan fisik yang dilakukan oleh Kasibuan terhadap Mariamin karena pertengkaran yang sering terjadi di antara mereka berdua yang disebabkan karena Kasibuan sudah membenci Mariamin. Hal ini dapat dibuktikan pada kutipan berikut.

"Pertengkaran yang serupa itu kerap kali kejadian di antara mereka itu, sehingga akhir-akhirnya Kasibuan yang bengis itu tak segan menampar muka Mariamin. Bukan ditamparnya saja, kadang-kadang dipukulinya, disiksainya..." Hal-163.

Berdasarka kutipan tersebut, tampak dengan jelas adanya kekerasan fisik yang dilakukan oleh kasibuan terhadap Mariamin berupa tamparan dan pukulan. Berdasarkan kutipan tersebut tampak bahwa pengarang secara tidak langsung menyampaikan kepada para pembaca perihal kekerasan yang dilakukan oleh Kasibuan kepada Mariamin berupa tamparan dan pukulan. Tamparan dan pukulan tersebut kerap kali dilakukan Kasibuan terhadap Mariain sebab pertengkaran yang sering terjadi di antara mereka berdua atas kecemburuan yang dirasakan oleh tokoh Kasibuan terhadap Mariamin. Sikap Kasibuan yang bengis menyebabkan ia dengan ringan tangan memperlakukan Mariamin dengan sangat kasar dan memperlakukan Mariamin dengan seenaknya. Mariaminpun tidak berani untuk melawan perlakuan yang diberikan oleh Kasibuan ini. Hal ini tentulah seharusnya tidak boleh terjadi dalam kehidupan berumah tangga. Mereka seharusnya saling mempercayai satu sama lain dan saling menyayangi sebagai sepasa suami istri.

\section{d. Kekerasan Fisik dalam Roman Salah Asuhan Karya Abdoel Moeis}

Pada roman Salah Asuhan karya Abdoel Moeis ini, terdapat bentuk kekerasan fisik yang dilakukan oleh Hanafi kepada Corrie istrinya. Tindak kekerasan ini terjadi saat Hanafi memberikan tuduhan selingkuh kepada Corrie. Hanafi yang naik pitam tidak percaya atas perkataan yang disampaikan oleh Corrie kepadanya. Kekerasan ini dapat dibuktikan dalam kutipan berikut. 
"Dengan perkataan itu diempaskannyalah sebuah pestol ke atas meja, lalu didapatkannya istrinya, sambil diketamnya tangan Corrie dalam genggamannya.

Corrie menjerit sebab kesakitan, lalu merentak-rentakkan tangannya, hendak melepaskan dia dari ketaman jari suaminya itu.

'Hai laki-laki pengecut! Apakah engkau hendak melakukan kekerasan kepada seorang istri yang tidak berdaya?" Hal-181.

Dari kutipan tersebut, tampak bahwa Corrie berusaha untuk memberontak atas perlakuan yang ia dapatkan dari Hanafi. Corrie memberontak dengan cara merentakrentakkan tangannya untuk membebaskan tangannya dari jari-jari Hanafi. Kekerasan yang diterima oleh Corrie ini menyebabkan Corrie pada akhirnya memilih untuk meninggalkan rumah dan menceraikan Hanafi. Hal ini dapat dibuktikan pada kutipan.

"Nah, kalau begitu terima kasih! Kau kumpulkanlah bukti-bukti dan saksisaksi buat Raad van Justice, supaya disahkan perceraian kita oleh pengadilan negeri. Buat saat ini aku hendak mendahului perceraian itu. Semenit pun aku tak sudi serumah lagi dengan engkau!" Hal-181.

Berdasarkan kutipan di atas, tampak bahwa Corrie sudah memutuskan untuk berpisah dengan Hanafi. Corrie menyuruh Hanafi untuk mencari saksi-saksi yang akan mereka bawa ke dewan kehakiman untuk sebagai syarat perceraian mereka dapat berlangsung.

\section{e. Kekerasan Fisik dalam Roman Sengsara Membawa Nikmat Karya Tulis Sutan Sati}

Pada roman Sengsara membawa Nikmat ini, tokoh Kacak selalu saja merundung tokoh Midun sebab rasa iri dengkinya pada Midun. Berdasarkan penelitian yang telah penulis lakukan, penulis menemukan bahwa dalam roman Sengsara Membawa Nikmat ini seringkali terjadi sebuah perkelahian antara Midun dengan Kacak. Perkelahian tersebut selalu terjadi dan di mulai oleh Kacak. Pada roman ini tampak bahwasannya Kacak sengaja selalu memulai sebuah perkelahian karena dirinya yang ingin menyelakai Midun.

Kekerasan fisik diterima oleh Midun sebab fitnah yang sudah dilontarkan oleh Kacak untuk Midun sehingga Tuanku Laras lebih mempercayai Kacak dari pada Midun. Fitnah yang disampaikan oleh Kcak ini ialah bahwa Midun sudah dengan sengaja menyelakai pak Inuh yang merupakan saudara dari Tuanku Laras. Fitnah tersebut pada akhirnya menyebabkan Tuanku Laras memberikan hukuman kepada Midun.

Hukuman yang diterima Midun tidaklah seberapa, namun karena pengawas dari hukuman tersebut adalah Kacak, maka Kacak memanfaatkan hal itu untuk membalaskan dendamnya kepada Midun. Kekerasan fisik yang dilakukan oleh Kacak terhadap tokoh Midun ini dapat dibuktikan pada kutipan berikut ini.

"Par! Pukulan Kacak tiba di punggung Midun. Midun hampir gelap pemandangannya. Kalau tidak lekas ia menyabarkan hatinya, tak dapat tiada sabitnya masuk perut Kacak. Dengan perlahan-lahan ia bangun, lalu berkata, 'Janganlah terlalu amat menyiksa saya, Engku Muda! Kesalahan saya tidak seberapa, tidak berpadanan dengan siksaan yang saya tanggung. Saya lihat 
Engku Muda seperti membalaskan dendam. Apakah dosa saya kepada Engku Muda? Terangkanla, kalau nyata saya bersalah, apapun juga hukuman yang Engku jatuhkan, saya terima." Hal-39.

Berdasarkan kutipan tersebut, tampak bahwa terjadi kekerasan fisik berupa pemukulan yang dilakukan oleh Kacak terhadap Midun. Kacak dengan sengaja memukul punggung Midun dengan cara yang kasar agar Midun tersiksa. Berdasarkan kutipan tersebut, tampak bahwa Kacak telah melakukan penganiayaan kepada Midun. Kacak bahkan tidak memberikan waktu istirahat untuk Midun. Midun sendiri tidak tau alasan sebenarnya mengapa Kacak begitu membenci dirinya. Pukulan serta perlakuan Kacak selama menjadi mandor di masa penahanan Midun tersebut telah menyebabkan Midun menjadi sangat tersiksa dan sangat teraniaya.

\section{Latar Sosial Budaya Tindak Kekerasan dalam Roman}

\section{a. Kebudayaan}

Terdapat perbedaan pendapat dalam roman angkatan 20-an terdapat dalam roman Salab Asuban kerya Abdoel Moeis. Pada roman ini perbedaan pendapat antara bangsa barat dan bangsa timur ini tercermin antara tokoh Hanafi dengan ibunya mengenai pelaksanaan adat istiadat Minangkabau yang selalu dijalankan oleh ibunya. Hal ini terjadi saat ibu Hanafi menyampaikan kepada Hanafi perihal dirinya yang yang diminta dengan saudara-saudara ibunya untuk menjadi seorang penghulu. Permintaan ini ditolak oleh Hanafi. Sebenarnya, sebelum ibu Hanafi menyampaikan kepada Hanafi perihal mamak-mamaknya yang ingin menjadikan Hanafi penghulu, permintaan tersebut telah di tolak lebih dulu oleh ibunya. Ibu Hanafi yakin, bahwa anaknya tidak akan mau patuh dan menuruti apa keinginan mamak-mamaknya tersebut.

Selain Hanafi yang ingin dijadikan penghulu oleh mamak-mamaknya, perbedaan pendapat antara Hanafi dan ibunya juga terjadi karena ibu Hanafi mengatakan bahwa Hanafi hendak dijadikan menantu oleh mamaknya yaitu Sutan Batuah. Mengetahui ihwal tersebut, Hanafi merasa tidak setuju sebab ia menganggap bahwa tidak ada orang di kampungnya yang bisa setara dengan dirinya yang sudah belajar dan bersekolah di sekolah Belanda. Hanafi menganggap bahwa tidak ada perempuan di kampungnya yang memiliki pendidikan yang sepadan dengan dirinya.

\section{b. Ekonomi}

Latar sosial berikutnya yang terdapat dalam roman angkatan 20 -an yaitu adanya ekonomi. Latar ekonomi ini terdapat dalam roman si Jamin dan si Johan karya Merari Siregar dan juga roman Azab dan Sengsara karya Merari Siregar. Latar ekonomi yang ada dalam roman angkatan 20-an ini ialah kemiskinan.

Kemiskinan ini merupakan sebuah fenomena sosial yang sudah ada dari sejak zaman dulu. Kemiskinan yang dirasakan oleh keluarga Jamin adalah fenomena kemiskinan yang terjadi di pinggiran kota Jakarta, yaitu kota yang besar dengan penduduknya yang padat. Kemiskinan yang terdapat dalam roman si Jamin dan si Johan ini tentu beda dengan kemiskinan yang terdapat dalam roman Azab dan Sengsara. 
Latar sosial ekonomi yang berupa kemiskinan yang terdapat pada roman Azab dan Sengsara ini merupakan fenomena kemiskinan yang terjadi di daerah perkampungan yaitu Minangkabau yang sangat kental dengan adat dan istiadatnya. Orang-orang di kampung tersebut sangat menjunjung tinggi nilai kekeluargaan peninggalan leluhur mereka. Hal inilah yang menjadi alasan mengapa Sutan Baringin di anggap hina dan di kucilkan di kampungnya. Sutan Baringin dianggap melenceng dari adat istiadat yang ada di kampungnya. Perbuatan Sutan Baringin inilah yang pada akhirnya menyebabkan Mariamin dan ibunya jadi terkena imbasnya. Kemiskinan yang mengikuti Mariamin ini menyebabkan ia tidak bisa mendapatkan sesuatu hal yang sudah lama sekali ia harapkan. Harapan Mariamin agar derajat keluarganya terangkat saat menikah dengan Aminudin harus pupus sebab ayah Aminudin yang tidak menyetujui pernikahan antara Aminudin dan Mariamin.

\section{c. Kekuasaan}

Latar sosial selanjutnya yang terdapat pada roman angkatan 20-an yaitu kekuasaan. Kekuasaan ini terdapat dalam roman Sitti Nurbaya karya Marah Rusli, roman Sengsara Membawa Nikmat karya Tulis Sutan Sati dan roman Salah Asuban karya Abdoel Moeis. Kekuasan menjadi latar sosial yang terdapat dalam roman angkatan 20-an sebab kekuasaan adalah hal yang mendominasi pada masa itu. Menurut Max Weber (dalam Santoso, 2001:59) mendefinisikan kekuasaan sebagai sebuah kesempatan yang dimiliki oleh seseorang atau sejumlah orang untuk melaksanakan keinginannya sendiri dalam suatu tindakan sosial, meskipun mendapat tantangan dari orang lain yang terlibat dalam tindakan itu. Kekuasaan disini dapat terjadi sebab karena kekayaan ataupun karena faktor keturunan dan juga faktor dominasi yang dimiliki oleh seseorang kepada orang lainnya.

Kekuasaan Datuk Meringgih pada roman Sitti Nurbaya merupakan kekuasaan yang ia dapatkan dari faktor kekayaan yang ia miliki. Datuk Meringgih yang pandai dalam urusan perniagaan membuat ia menjadi salah seorang yang paling kaya di kampungnya. Gelar Datuk yang disandang oleh Datuk Meringgih ini ia dapatkan sebab orang-orang di kampungnya yang segan terhadap kekayaan yang dimiliki oleh Datuk Meringgih. Kekuasaan yang dimiliki Datuk Meringgih ini pun menyebabkan ia mejadi orang yang tamak akan harta. Orang-orang di kampung pun menghormatinya lantaran segan atas kekayaannya saja, namun mereka sendiri sejatinya tidak menyukai perwatakan atau karakteristik dari Datuk Meringgih sendiri.

Kekuasaanya selanjutnya ialah kekuasaan yang dimilki oleh Kacak dalam roman Sengsara Membawa Nikmat oleh Tulis Sutan Sati. Beda halnya dengan kekuasaan yang dimiliki oleh Datuk Meringgih, kekuasaan yang dimiliki Kacak ia dapatkan dari garis keturunan yaitu Tuanku Laras. Kacak adalah keponakkan Tuanku Laras. Pada roman ini, terdapat satu orang yang sangat dibenci oleh kacak, yaitu Midun. Kacak sangat membenci Midun sebab orang-orang di kampungnya lebih banyak yang menyenangi Midun dibanding dirinya. Kacak merasa iri akan hal itu.

Kekuasaan selanjutnya terdapat dalam roman Salab Asuban oleb Abdoel Moeis. Penulis menemukan bahwa dalam roman Salah Asuhan karya Abdoel Moeis ini, terdapat kekuasaan yang dimiliki oleh bangsa pribumi terhadap diri Hanafi itu membuat dirinya menjadi tersiksa. Pemberontakan-pemberontakan yang dilakukan oleh Hanafi pun kerap ia lampiaskan kepada ibunya dan juga Rapiah yang merupakan 
istri Hanafi. Jiwa kebarat-baratan yang dimiliki oleh Hanafi ini juga didorong dari kehadiran tokoh perempuan yang Hanafi cintai, yaitu Corrie. Corrie adalah cinta pertama Hanafi sejak ia bersekolah di sekolah Belanda. Percintaan Hanafi dan Corrie ini ditentang oleh orang tua Hanafi terutama ibu Hanafi tidak menyetujui percintaan mereka berdua karena Corrie yang berasal dari bangsa Barat.

\section{PENUTUP}

Hasil dari penelitian dan pembahasan tentang roman angkatan 20-an dapat disimpulkan bahwa terdapat dua bentuk kekerasan yang terjadi dalam roman angkatan 20-an yaitu kekerasan verbal yang merupakan tindak kekerasan yang dilakukan melalui ucapan atau perkataan sehingga menyebabkan korban menjadi teraniaya dan tidak berdaya dalam melakukan perlawanan terhadap pelaku. Berdasarkan penelitian yang telah penulis lakukan, penulis menemukan bahwa bentuk kekerasan verbal dalam roman angkatan 20an ini banyak terjadi pada kaum perempuan. Selain kekerasan verbal, penulis juga menemukan adanya bentuk kekerasan fisik yang terdapat dalam roman angkatan 20-an. Kekerasan fisik ini merupakan kekerasan yang melibatkan kontak fisik secara langsung yang menyebabkan koban menjadi cidera, terluka hingga meninggal dunia.

Kekerasan-kekerasan tersebut muncul sebagai tindak lanjut dari konflik sosial yang terjadi dalam roman tersebut yang merupakan sebuah cerminan dari fenomena sosial yang terjadi pada zaman tertentu. Fenomena sosial yang didasari oleh latar sosial dalam roman angkatan 20-an tersebut terbagi menjadi tiga latar sosial budaya antara lain yaitu (1) kebudayaan yang terdapat dalam roman Salah Asuhan karya Abdoel Moeis, (2) ekonomi yang terdapat dalam roman si Jamin dan si Johan karya Merari Siregar dan roman Azab dan Sengsara karya Merari Siregar dan (3) kekuasaan dalam roman Sitti Nurbaya karya Marah Rusli, roman Sengsara Membawa Nikmat karya Tulis Sutan Sati dan roman Salah Asuhan karya Abdoel Moeis. Disarankan ada penelitian selanjutnya terhadap roman angkatan-20an yang mengkaji khusus mengenai nilai-nilai kebudayaan yang terdapat dalam roman angkatan 20-an.

\section{DAFTAR RUJUKAN}

Anak, K. P. (t.thn.). Dipetik April 20, 2021, dari Kemenpppa Web Site: https://www.kemenpppa.go.id/lib/uploads/list/8e022-januari-ratas-bullyingkpp-pa.pdf

Pradopo, R. D. (1995). Beberapa Teori Sastra, Metode Kritik, dan Penerapanya. Yogyakarta: Pustaka Pelajar.

Prawestiningtyas, E. (2017). Kekerasan pada Anak dan Aspek Medikolegal. Prosiding Pertemuan Ilmiah Tabunan 2017 (hal. 113). Pekanbaru: Perhimpunan Dokter Forensik Indonesia.

Ratna, N. K. (2013). Paradigma Sosiologi Sastra. Yogyakarta: Pustaka Belajar.

Santoso, T. (2001). Kekuasaan dan Kekerasan. Masyarakat, Kebudayaan dan Politik, 93. 